\title{
Delving into Students' Attitude towards Teaching and Learning Process: An Appraisal Analysis of Course Review
}

\author{
Nina Setyaningsih ${ }^{1}$, Anisa Larassati ${ }^{2}$ \\ Universitas Dian Nuswantoro, J1. Imam Bonjol 207 Semarang, Indonesia ${ }^{1,2}$ \\ \{1nina.setyaningsih@dsn.dinus.ac.id, 22anisa.larassati@dsn.dinus.ac.id\}
}

\begin{abstract}
Teaching and learning process reviews can be used to obtain information about lecturers' teaching performance. They may become a useful input for the lecturers and their students. For lecturers specifically, the reviews may increase the teaching and learning process quality. This study investigates the students' reviews of their previous semester's grammar courses through the Appraisal framework (Martin and White, 2005). It focuses on the students' Attitude, including Affect, Judgment, and Appreciation. The result reveals that Affect deals with the students' emotional reactions and personal hopes towardsthe grammar classes, Judgment with the students' assessment of the lecturer's teaching skills, while Appreciation with the students' valuation on the lecturers and the importance of the grammar courses. This research also suggests that the course review not only presents the students' inputs for the teaching and learning process in the grammar class but also depicts their skills in applying grammatical rules in writing.
\end{abstract}

Keywords: appraisal, attitude, EFL, review

\section{INTRODUCTION}

Lecturers sometimes face a challenge in finding out and understanding students' difficulties in grasping course materials. On the other hand, one of the goals of teaching is to promote learning. Increasing the students' learning quality will inevitably involve improving the quality of the lecturers. There are many ways to achieve this. Not only do trainings and workshops on teaching are useful for lecturers, but inputs from students may also provide valuable resource for lecturers. Sometimes students' inputs may not be considered since traditionally teaching and learning process focuses mainly on the teachers or lecturers instead of the students. One of the ways to generate inputs from students is by giving questionnaires. In Universitas Dian Nuswantoro, students are required to fill in a questionnaire by the end of semester in their academic information system. However, since the questionnaire consists of multiple choice questions (closed questionnaire), the students' inputs in the form of reviews of the course cannot be obtained. Pertaining to this problem, having students write a review of their previous courses in the first meeting of the following semester may help the lecturers to get an insight of the students' problems in understanding the materials and their attitude towards the teaching and learning process. 
This research examines the reviews written by the students of the English Department in two grammar courses taught in the first and second year respectively. The reviews are in the form of commentaries of the students' previous semester's grammar courses. It is widely known that grammar is a challenging subject for Indonesian students in the English as a foreign language (EFL) classes. Therefore, a review of the previous class is considered useful for the lecturer to help her understand the students' difficulties and expectation in the teaching and learning process. To reveal the students' attitude, the reviews were analyzed by using Appraisal framework (Martin and White, 2005).

\subsection{Appraisal, the Language of Evaluation}

The appraisal framework, which provides the tool to analyze meanings conveyed in text, was first developed in the 1900s and 2000s particularly by Martin and White. It is based on the Halliday's systemic functional linguistics theory which suggests that meaning-making can be divided into three "metafunctions", namely (1) "ideational" meaning, (2) "interpersonal" meaning, and (3) "textual" meaning. (1) "Ideational" meaning deals with how language defines the world of experience;(2) "interpersonal" meaning deals with how speakers/writers define social roles, personas, and relationships, and (3) "textual" meaning deals with how ideational and interpersonal meanings are combined to build coherent texts for appropriate communicative setting (Halliday, 1994). In relation to Halliday's metafunctions, "interpersonal" meaning can be realized through appraisal as they both concern with expressing one's feelings. Appraisal framework enables the researcher to analyze positive or negative assessments in a text, as well as how the intensity or directness of such attitude is strengthened or weakened. These aspects are also known as the "language of evaluation" as they show the speaker's or writer's personal evaluative involvement toward some phenomena or metaphenomena (White, 2015). Appraisal can be categorized into three domains, namely 'attitude', 'engagement' and 'graduation'. Attitudes concerns with one's feelings, such as emotional reactions, judgments of behaviors and evaluation of things. Engagement deals with "positioning the speaker's or author's voice in relation to the various proposition and proposals conveyed by text". Graduation deals with grading the phenomena which related to one's feelings. (Martin and White, 2005).

Appraisal has been widely used to analyze different types of discourse. Li (2016) analyzed the Attitude of English songs. Her study reveals that Attitude in the songs reflect the Western Humanities thought. Appraisal has also been used in political discourse analysis, such as one conducted by Ding (2017). The author, who analyzed Barack Obama's victory speech, found that several appraisal resources were used in the speech which eventually resulted in his success. As this research focuses on students' evaluation on their grammar teaching and learning process, attitude is the most relevant domain to discuss here.

\subsection{Attitude: Expressing Feelings}

The system of meanings which deals with the outlining of feelings as they are represented in English texts is referred to as attitude. Attitude itself is divided into three subcategories, namely 'affect', 'judgment', and 'appreciation'.

Affect refers to the emotive dimension of meaning. It concerns with the positive and negative feelings, such as happiness or sadness, confidence or anxiousness, interest or boredom. Judgment deals with evaluating behavior which one may admire or criticize, praise 
or condemn, while appreciation involves the assessment of artifacts, entities, happenings, and state of affairs (Martin and White, 2005).

\section{METHODOLOGY}

This reseach is a descriptive qualitative, i.e., it generates findings not arrived at by statistical procedures or other means of quantification (Strauss and Corbin, in Snape and Spencer, 2003: 3). Furthermore, it studies things in their natural settings, attempting to make sense of, or to interpret, phenomena in terms of the meanings people bring to them (Denzin and Lincoln, in Snape and Spencer, 2003: 3). It is intended to analyze the students ${ }^{\text {' attitudes }}$ towards teaching and learning process in the grammar class. It describes how interpesonal meanings are realized in the reviews by using Appraisal framework. The data of the research were collected from students' reviews gathered by the lecturer in the first meeting of the course. There were 50 reviews randomly taken from a total of 180 reviews. The unit of analysis consists of clauses, phrases, or words containing appraisal devices. The Attitude system which includes affect, judgement, and appreciation was therefore identified from those elements.

\section{FINDINGS AND DISCUSSION}

Table 1 demonstrates the findings of the research. Affect is mostly used in the students reviews, followed by Appreciation and Judgment. Affect relates to the students ' emotional reaction towards the grammar classes. The highest occurence of Affect belongs to Inclination, as the students expressed their hopes and wishes regarding the grammar teaching and learning process and the outcome of the process. Judgment is concerned with the students' assessment of the lecturer's teaching skills. The highest percentage of Judgment type belongs to Capacity. It deals with the lecturer's capability of delivering the materials. Meanwhile, Appreciation is related with the students' evaluation towards the lecturers and the grammar courses. The type of Appreciation that has the highest percentage is Composition, which is related to students ${ }^{6}$ perception of the grammar courses, specifically, the complexity of the subjects or topics and the way the lecturer delivered the materials.

Table 1. Findings of Attitude in the Students' Grammar Course Reviews

\begin{tabular}{ccccc}
\hline Attitude Subsystems & Types & Amount & Subtotal & Frequency \\
\hline Affect & Inclination & 29 & & \\
& Happiness & 7 & 54 & $46.96 \%$ \\
& In/security & 18 & & \\
\hline Judgment & Capacity & 13 & & \\
& Normality & 7 & 23 & \\
& Veracity & 2 & & \\
& Propriety & 1 & & \\
& Tenacity & 1 & 38 & $33.04 \%$ \\
& Composition & 29 & & \\
\hline Appreciation & Reaction & 7 & $\mathbf{1 1 5}$ & $\mathbf{1 0 0 \%}$ \\
\hline
\end{tabular}

The following section discusses the description of the findings. It is worth noting that the data excerpts are intentionally so typed based on what the students wrote in their reviews, 
thus any grammatical errors were not considered in the analysis. Furthermore, the names of the lecturers are simply written as Lecturer here for the sake of confidentiality.

\subsection{The Realization of Affect}

Affect concerns with emotional states and responses. In the students' reviews, three types of Affect are found, namely In/security, Happiness, and Inclination. Happiness exhibits the students' emotional feelings towards the previous grammar courses, Insecurity with the students ' feelings of anxiety and inconfidence in grammar, and Inclination with the students expression of their personal desire towards grammar. In general, the students basically liked to study grammar and hoped that they could improve their skill and understanding in English grammar. Furthermore, they felt happy when they understood the topic being discussed. They also liked the way the lecturer taught them, especially because the lecturer was quite flexible and not too strict with class rules. The lecturer also often made some jokes in the classroom so they could enjoy the class.

\section{Affect : Inclination}

Inclination is related with the students'personal hope and wish in the teaching and learning process of the grammar courses. The students hoped that they could understand the materials easily and better than before and that they could get and improve their score. They also hoped that the lecturers taught them more slowly and clearly since in the previous grammar classes, some lecturers taught them (and possibly spoke) so fast that they felt difficult to grasp the materials. They also hoped that the lecturers gave them more examples to help them get better understanding. The excerpts are presented below.

[Review 4] I hope that in this semester I can understand all the materials/ lessons. Looking forward to this semester.

[Review 46] I hope in this semester, I can understand English Grammar better than before. And I hope Lecturer] can explain clearly.

\section{Affect : Happiness}

This Affect type involves emotions that is concerned with the students's positive feelings, and in this case, they felthappy when they studied grammar. They liked the materials that they could understand well. They also liked the way the lecturer taught them. The following excerpts demonstrates the realization of Affect : Happiness.

[Review 20] I like when learning to distinguish gerund or gerund phrases and I have difficulties when distinguishing verbs or nouns.

[Review 44] In last semester I liked the way [Lecturer] teach us. So I enjoyed the class.

\section{Affect : Insecurity}

Insecurity includes emotions concerned with anxiety, fear, or confidence. The students felt insecure when they found material or topic they thought difficult, when they didn't know how grammatical rules work, or when they didn't feel confident with their answer, especially at times they were working on exercises or exam. It can be seen in the following excerpts:

[Review 2] And I felt not confidence with my answer. Just like "Is this the right answer or another one is the right answer".

[Review 36] I like grammar but I am still feel difficult to understanding how grammar use. 


\subsection{The Realization of Judgment}

Judgment deals with the students' attitude to the lecturers and their characters. The data also show that Judgment not only relates to their evaluation about their lecturers, but also deals with the students' attitude towards their own behavior while studying grammar.

\section{Judgment : Normality}

This type of Judgment evaluates how unusual someone is. In this context, the students evaluate the behavior of their lecturers in the classroom. Lecturers are normally expected to give clear explanation about the course they teach, to give relevant materials for the course, and to attend the class as scheduled. However, it is found in the data that most of the students gave negative evaluation (criticize) the lecturers' manner of teaching for being too fast and unclear. It is also mentioned that some lecturer rarely attended the class and gave too many materials. It can be seen in the following excerpts:

[Review 15] the lecture never entered the class.

[Review 16] lecturer often dont attend class last semester.

[Review 45] First grammar 1, maybe probably in noun phrase and changed noun to verb, noun to adverb because the lecture doesn't explain clearly.

[Review 46] [Lecturer] wrote in the blackboard and explained it. But I don't really understand, because he was too fast when explained the material and his hand writing was so bad.

\section{Judgment : Capacity}

Capacity reflects the evaluation about one's capability and it answers question such as "how capable are they?". In this research, the capacity being reviewed is not only that of the lecturers' but also the students'._As for the capacity evaluation directed to the students, most of them gave negative evaluation on their own capability of understanding the course. They admitted that they were incapable of understanding the materials and easily forgot them. It is also mentioned that they could not write in a correct grammar. Hence, they admitted their incompetence (negative capacity) as shown in the following excerpts:

[Review 6] In another words I can easily forget about the material.

[Review 21] I dont understand about gerund and how to distinguish between gerund and present participle and I cant writing with grammatically.

Regarding the capacity evaluation directed to the lecturers, the results of the students' reviews show that the lecturers taught the subject too fast and unclearly. Hence, they give negative evaluation for their capability in teaching the subject as seen in the following excerpts:

[Review 10] I started difficultduring second semester. Often forget about the materials and teach it too fast.

[Review 47] And I didn't really understand all the lesson. Because the lecturer didn't teach in detail. So I didn't understand on it.

\section{Judgment : Tenacity}

In some courses such as grammar, students rely on examples given by the lecturers. The more examples of grammatically correct sentences they get, the easier they produce such sentences. However, students feel that some of the lecturers rarely gave them such examples. 
Thus, it makes them give negative evaluation on the lecturers' tenacity as they feel that they are undependable. It is shown in the following excerpt:

[Review 17] I understand about the courses but I think there's something missing like less for giving example or something like that.

\section{Judgment : Veracity}

Veracity deals with how honest or truthful someone is. In this context, the students stated that their opinion about grammar (that it was a very hard course) is true and that their opinion about this course is honest. The following excerpts show the example of veracity evaluation:

[Review 45] I thought grammar was very hardcourse and it was true.

[Review 9] In my honest opinion, grammar is difficult lesson.

\section{Judgment : Propriety}

Propriety relates with ethic and answer questions such as 'how far beyond reproach?'. In this context, students expected that the lecturers explained the course clearly before giving them any questions to answer. However, one of the lecturers gave them so many questions, whereas they did not understand the lesson yet. For them it is evaluated as unfair. Thus, it makes them give negative evaluation for propriety as seen in the following excerpt:

[Review 44] [Lecturer]always give us a lot of questions when we are don't understand it yet

\subsection{The Realization of Appreciation}

Appreciation is concerned with meanings construing the students' evaluations of the grammar courses. In this research, three types of Appreciation are found, namely Composition, Valuation, and Reaction. Composition is related to the students' perceptions of the grammar courses, especially concerning the complexity of grammatical items. Valuation deals with the students' considered opinions towards the importance of the course and the role of the lecturers. Reaction relates with the students' interpersonal significance of the grammar courses.

\section{Appreciation : Composition}

Composition refers to the complexity of the matters dealing with the grammar course and the way the lecturer taught. It also refers to whether or not the teaching and learning process is hard to follow. The reviews present negative appreciation of Composition, in that that most of the students consider grammar as a difficult course. However, some students also found grammar easy, especially when they could understand the material.

[Review 7] I have passed 3 semester and grammar is one of the most difficult course.

[Review 9] In my honest opinion, grammar is difficult lesson. In my first semester, learning about basic of grammar, is not too difficult. But in the second till third semester it so difficult $\underline{\text { lesson }}$ and difficult for me to understand.

As previously mentioned, negative evaluation of Composition does not only relate with the complexity of grammar. The students gave negative evaluation to the way the lecturer 
explained the materials. They also had trouble in reading the lecturer's handwriting on the whiteboard, hence adding their difficulty in the grammar course.

[Review 50] Me, studying grammar for the last semester is a little bit difficult to understanding. Because the lecture's writing is hard to read, and the way he explain it is a little bit hard to understanding.

\section{Appreciation : Valuation}

Valuation is related to the students ${ }^{6}$ opinion about grammar and the teaching and learning process.In the data, the students pointed out the role of the lecturer in the class. They also considered grammar hard but important.Hence, when they faced difficulties, they viewed that the lecturer also played an important role in making them understand the materials. Besides understanding of the material and being able to write and speak grammatically, the studentsalso expected that they could get a good scorein the subject.

[Review 12] But I think, the lecturer role is importandt too to make students understand.

[Review 18] I want to more understand about english grammar than before because I think thats really important.

\section{Appreciation : Reaction}

Reaction describes the emotional effect of the grammar teaching and learning process on the students. In this context, positive reactions are found in the evaluation concerning the grammar course, while negative reaction deals with students' evaluation of their achievement and ability. It is shown in the following excerpts:

[Review 6] I really bad in remembering something.

[Review 34] Impression of learning grammar for 3 semesters I can add to the understanding of conditional sentences, and my favorite materials in grammar are adverb, adj and noun clause.

\section{CONCLUSION}

Various types of Attitudes have been used by the students in the review. Affect is related to the students' positive and negative emotional reactions and personal hopes towards the grammar classes. Judgment deals with the students' positive and negative evaluations of their own abilities in understanding grammar materials and the lecturer's teaching skills. Appreciation is concerned with the students' valuation on the lecturers' ${ }^{6}$ role and the importance of the grammar courses. These findings indicate that both hard skill and soft skill are essential in the teaching and learning process of grammar in EFL classes since grammar still becomes a challenging subject for many students. Moreover, this research also suggests that course review can be a useful tool to delve into students' needs and wants in the grammar teaching and learning process. It does not only portray students' inputs for lecturers but also depicts their skills in applying accurate grammatical rules in writing. Lecturers may consider this as an overview of their students" entry behaviors to decide what teaching strategies are most suitable for the students.

\section{References}

[1] Ding, Ailan. (2017). The Analysis of Attitudinal Resources in Obama's Victory Speech from Perspective of Appraisal Theory. Higher Education of Social Science Vol. 12, No. 1, pp.37-44, DOI:10.3968/9376 
[2] Halliday, M.A.K (1994) An Introduction to Functional Grammar. 2nd edn. London: Edward Arnold.

[3] Li, Xiaqing. (2016) "An Attitudinal Analysis of English Song Discourse from the Perspective of Appraisal Theory," Journal of Language Teaching and Research, Vol. 7, No. 3, pp. 559-565, DOI: http://dx.doi.org/10.17507/jltr.0703.17

[4] Martin, J. R., \& White, P. (2005). The language of evaluation: appraisal in English. New York: Palgrave Macmillan Ltd.

[5] Snape, Dawn and Liz Spencer. (2003). The Foundations of Qualitative Research. Qualitative Research Practice A Guide For Social Science Studentsand ResearchersEdited by Jane Ritchie and Jane Lewis, London: Sage Publications Ltd.

[6] White, Peter R. (2015). Appraisal Theory. The International Encyclopedia of Language and Social Interaction, First Edition. Karen Tracy (General Editor), Cornelia Ilie and Todd Sandel (Associate Editors). JohnWiley \& Sons, Inc. DOI: 10.1002/9781118611463/wbielsi041 